\title{
Impact of a public policy restricting staff mobility between long-term care homes in Ontario, Canada during the COVID-19 pandemic
}

Aaron Jones ${ }^{\mathrm{a}, \mathrm{b}}, \mathrm{PhD}$, Alexander G. Watts ${ }^{\mathrm{c}}$, PhD, Salah Uddin Khan ${ }^{\mathrm{c}}, \mathrm{PhD}$, Jack Forsyth ${ }^{\mathrm{c}}, \mathrm{BES}, \mathrm{Kevin} \mathrm{A}$.

Brown $^{\mathrm{d}, \mathrm{e}}$, PhD, Andrew P. Costa ${ }^{\mathrm{a}, \mathrm{b}, \mathrm{f}}, \mathrm{PhD}$, Isaac I. Bogoch ${ }^{\mathrm{g}, \mathrm{h}}, \mathrm{MD}$, Nathan M. Stall ${ }^{\mathrm{g}, \mathrm{ij}, \mathrm{k}}, \mathrm{MD}$

${ }^{a}$ Department of Health Research Methods, Evidence, and Impact, McMaster University, Hamilton Ontario, Canada.

${ }^{\mathrm{b}}$ ICES, Toronto, Ontario, Canada

${ }^{c}$ BlueDot, Toronto, Ontario, Canada

${ }^{d}$ Public Health Ontario, Toronto, Ontario, Canada

e Dalla Lana School of Public Health, University of Toronto, Toronto, Ontario, Canada

${ }^{f}$ St. Joseph's Health System, Hamilton, Canada

${ }^{\mathrm{g}}$ Department of Medicine, University of Toronto, Toronto, Ontario, Canada

${ }^{\mathrm{h}}$ Divisions of General Internal Medicine and Infectious Diseases, University Health Network, Toronto, Canada

'Institute for Health Policy, Management, and Evaluation, University of Toronto, Toronto, Ontario, Canada

${ }^{j}$ Divisions of General Internal Medicine and Geriatrics, Sinai Health System and the University Health Network, Toronto, Ontario, Canada

${ }^{k}$ Women's College Research Institute, Women's College Hospital, Toronto, Ontario, Canada

\section{$\underline{\text { Abstract }}$}

Objectives: To assess changes in the mobility of staff between long-term care homes in Ontario, Canada before and after enactment of public policy restricting staff from working at multiple homes.

Design: Pre-post observational study.

Setting and Participants: 623 long-term cares homes in Ontario, Canada between March 2020 and June 2020.

Methods: We used anonymized mobile device location data to approximate connectivity between all 623 long-term care homes in Ontario during the 7 weeks before (March 1 - April 21) and after (April 22 - June 13) the policy restricting staff movement was implemented. We visualized connectivity between longterm care homes in Ontario using an undirected network and calculated the number of homes that had a connection with another long-term care home and the average number of connections per home in each 
medRxiv preprint doi: https://doi.org/10.1101/2020.11.17.20231498; this version posted November 18, 2020. The copyright holder for this preprint (which was not certified by peer review) is the author/funder, who has granted medRxiv a license to display the preprint in perpetuity.

It is made available under a CC-BY-NC-ND 4.0 International license .

Mobility changes between LTC homes in Ontario 2

period. We calculated the relative difference in these mobility metrics between the two time periods and compared within-home changes using McNemar's test and the Wilcoxon rank-sum test.

Results: In the period preceding restrictions, 266 (42.7\%) long-term care homes had a connection with at least one other home, compared to $79(12.7 \%)$ homes during the period after restrictions, a drop of $70.3 \%(p<0.001)$. The average number of connections in the before period was 3.90 compared to 0.77 in after period, a drop of $80.3 \%$ ( $p<0.001)$. In both periods, mobility between long-term care homes was higher in homes located in larger communities, those with higher bed counts, and those part of a large chain.

Conclusions and Implications: Mobility between long-term care homes in Ontario fell sharply after an emergency order by the Ontario government limiting long-term care staff to a single home, though some mobility persisted. Reducing this residual mobility should be a focus of efforts to reduce risk within the long-term care sector during the COVID-19 pandemic.

\section{$\underline{\text { Introduction }}$}

Worldwide, residents of long-term care (LTC) homes have been disproportionately affected by the COVID-19 pandemic. ${ }^{1}$ In Canada, nearly 80\% of all COVID-19 deaths have occurred among LTC home residents, the highest known proportion among developed countries. ${ }^{2,3}$ Residents of LTC homes are at disproportionately increased risk of both COVID-19 infection and poor COVID-19 outcomes, as a result of congregate living, advanced age, frailty and multimorbidity. ${ }^{4}$

Early in the pandemic, healthcare workers were identified as important and unknowing vectors for importation of COVID-19 into LTC homes, with movement of staff between LTC homes and other healthcare settings being key contributors to the spread of COVID-19. ${ }^{5-7}$ Staff in LTC homes are frequently employed on a part-time or casual basis, requiring individuals to work in multiple homes or health care settings to earn a living wage. 8 
medRxiv preprint doi: https://doi.org/10.1101/2020.11.17.20231498; this version posted November 18, 2020. The copyright holder for this preprint (which was not certified by peer review) is the author/funder, who has granted medRxiv a license to display the preprint in perpetuity.

It is made available under a CC-BY-NC-ND 4.0 International license .

Mobility changes between LTC homes in Ontario 3

When COVID-19 outbreaks intensified in LTC homes during the first months of the pandemic, numerous jurisdictions enacted policies to limit the movement of LTC staff between multiple homes. ${ }^{10-12}$ On April $22^{\text {nd }}, 2020$, Canada's most populous province of Ontario implemented an order that prevented staff from working in more than one home. Recognizing that existing staffing shortages were exacerbated by the COVID-19 pandemic, ${ }^{13}$ the order did not apply to temporary agency workers or other contract staff, in order to ensure LTC homes had an availability of staff to work on an emergency basis. ${ }^{14,15}$ We used anonymized mobile GPS location data to examine the impact of this order on mobility between LTC homes.

\section{Methods}

\section{Setting and Study Design}

We conducted a pre-post observational study of mobility between LTC homes in Canada's most populous province of Ontario (population approximately 15 million residents). Medical and personal care in LTC homes are covered by Ontario's universal and publicly funded health insurance plan, with residents responsible for an accommodation copayment. Currently, there are over 70,000 residents in 623 longterm care homes in Ontario. ${ }^{16}$

\section{Data sources}

We obtained all data for this study as part of the COVID-19 Ontario Census Modelling Table. The Modelling Table is sponsored by the Ontario Ministry of Health, Ontario Health, and Public Health Ontario and is an ad-hoc and voluntary group of senior decision-makers and scientists tasked with creating credible consensus estimates of the impact of COVID-19. We used anonymized, populationaggregated, near-real-time, mobile device GPS location data provided by Veraset (Veraset, San Francisco, CA), a data-as-a-service vendor. Verasat aggregates location data across several apps on both Apple and Android platforms after the user has consented to use of their anonymized data, and has been previously 
medRxiv preprint doi: https://doi.org/10.1101/2020.11.17.20231498; this version posted November 18, 2020. The copyright holder for this preprint (which was not certified by peer review) is the author/funder, who has granted medRxiv a license to display the preprint in perpetuity. It is made available under a CC-BY-NC-ND 4.0 International license .

Mobility changes between LTC homes in Ontario 4

used in research. ${ }^{7,17}$ Data on long-term care home characteristics and COVID-19 outbreaks were obtained from the Ontario Ministries of Health and Long-Term Care. The study was approved by the Research Ethics Board of (masked).

\section{Emergency order}

On April 15, 2020 the Government of Ontario announced an emergency order restricting employees of LTC homes from working in more than one LTC home, congregate care or healthcare setting within a 14day period. The order came into effect on April 22, 2020, but did not apply to temporary agency staff or other contract staff (who are not employees of LTC homes), in order to ensure LTC homes had an availability of staff to work on an emergency basis location ${ }^{18}$.

\section{Mobility between long-term care homes}

We evaluated mobility between LTC homes in two time periods before and after implementation of the emergency order: March 1 - April 21, 2020 (the "before" period) and April 22 - June 13, 2020 (the "after" period). We used Statistics Canada's Open Database of Buildings to define home location and footprint ${ }^{19,20}$. For homes where there was no entry in the database, we defaulted to a 50 -meter buffer around a home's latitude-longitude coordinates. A visit to a home occurred if a device had GPS check-ins within a LTC home's boundary in two consecutive half-hour time blocks with a minimum total elapsed time of thirty minutes, thereby selecting visits that are likely to be staff entering homes rather than transient visits due to deliveries, etc. A connection between two homes was recorded if the same device had visits to two separate homes within 14 days. Of note, the Province of Ontario restricted visitors to LTC homes from March 14-June 18, 2020 with the exception of end-of-life compassionate visits, meaning that mobility devices captured within our study period would very likely be limited to residents and staff.

We calculated mobility metrics for each LTC home based on the connections in which it was the destination home, i.e. a device entered the home after being detected in a different LTC home in the 
medRxiv preprint doi: https://doi.org/10.1101/2020.11.17.20231498; this version posted November 18, 2020. The copyright holder for this preprint (which was not certified by peer review) is the author/funder, who has granted medRxiv a license to display the preprint in perpetuity.

It is made available under a CC-BY-NC-ND 4.0 International license .

Mobility changes between LTC homes in Ontario 5

previous 14 days. For each home we calculated whether there was any connection with another LTC

home and the total count of connections with other homes.

\section{$\underline{\text { Analysis }}$}

We constructed an undirected network connectivity diagrams for periods before and after restrictions were implemented. We identified homes in COVID-19 outbreak ( $\geq 1$ resident or staff case) during any part of each period on the diagrams. For each of our network metrics, we calculated the average for the before and after periods, and the relative difference (expressed as a percentage) between the two time periods. We reported these measures overall and by home size (number of licensed beds), community size (population), for-profit status (for-profit, non-profit or municipal), and chain size (single home, small chain [2-19], or large chain [ $\geq 20])$. Homes owned by municipalities were not considered part of a chain. We performed within-home comparisons of the mobility metrics between the periods using McNemar's test and the Wilcoxon signed-rank test. Analysis was done using R 4.0.0 21,22 .

\section{Results}

We identified 5,640 unique mobile devices that entered at least one of Ontario's 623 LTC homes in the 7 weeks before enactment of an emergency order restricting staff mobility between LTC homes (March 1 April 21, 2020) and 3,792 unique devices that entered in the 7 weeks after enactment of the order (April 22 - June 13, 2020). Prior to the emergency order, 266 (42.7\%) LTC homes had a connection with at least one other LTC home, compared to $79(12.7 \%)$ homes following the order, a drop of $70.3 \%(p<0.001)$

(Figure 1 and Table 1). The average number of connections was 3.90 in the time period before the order and 0.77 in the time period following the order, corresponding to a drop of $80.3 \%(p<0.001)$. Mobility between LTC homes was higher in homes located in larger communities, in those with higher bed counts, and those part of a large chain. During the after period, $72(30.2 \%)$ of homes with $\geq 200$ beds still had at least one connection compared to 65 (1.5\%) of the homes with $\leq 20$ beds and 145 (17.9\%) of the large 
medRxiv preprint doi: https://doi.org/10.1101/2020.11.17.20231498; this version posted November 18, 2020. The copyright holder for this preprint (which was not certified by peer review) is the author/funder, who has granted medRxiv a license to display the preprint in perpetuity.

It is made available under a CC-BY-NC-ND 4.0 International license .

Mobility changes between LTC homes in Ontario 6

chain homes had a connection compared to $268(9.3 \%)$ of the homes that were not part of a chain. There were 149 (23.9\%) homes in outbreak at any point during the before period, and 292 (46.9\%) homes in outbreak at any point during the after period.

\section{Discussion}

Mobility between LTC homes in the Province of Ontario dropped sharply after implementation of an emergency order restricting staff to work a single home. The number of LTC homes with any connection to another home fell by $70.3 \%$ while the total number of connections dropped by $80.3 \%$. In spite of this, 12.7\% of all Ontario LTC homes still had connections following enactment of the emergency order.

Staff mobility between LTC homes has been identified as an important vector for importation of COVID19 into and spread between homes, and many jurisdictions have therefore restricted or limited workers from working in multiple healthcare settings. Ontario's emergency order came into force three and half weeks after the first reported COVID-19 outbreak in a LTC home (March 29 to April 22, 2020), at which point nearly 150 homes had experienced an outbreak. ${ }^{7}$ Other Canadian provinces like British Columbia responded somewhat faster, limiting mobility in just under three weeks after their first reported outbreak (March 7 to March 26, 2020) ${ }^{13}$, at which point only 9 homes were in outbreak. ${ }^{24}$ Given the robust drop in mobility we observed in our study, and other research linking higher staff mobility to increased COVID-19 incidence in LTC homes, delays in limiting mobility may have resulted in additional cases and deaths among LTC residents and staff. ${ }^{7,25}$

The ongoing connectivity of 79 (12.7\%) of Ontario's 623 LTC homes following implementation of the order merits serious consideration, especially as decision-makers and the LTC sector grapple with the intensifying second wave of the COVID-19 pandemic. This connectivity could represent non-compliance with the provincial order or movement of individuals not covered by the order such as physicians who work at multiple homes. The persistent connectivity may represent Ontario exempting temporary agency 
medRxiv preprint doi: https://doi.org/10.1101/2020.11.17.20231498; this version posted November 18, 2020. The copyright holder for this preprint (which was not certified by peer review) is the author/funder, who has granted medRxiv a license to display the preprint in perpetuity.

It is made available under a CC-BY-NC-ND 4.0 International license .

Mobility changes between LTC homes in Ontario 7

workers and contract staff from the ban on working at more than one home or healthcare setting. Any residual mobility remains a potential vector for the importation of COVID-19 into LTC homes and closing the loophole on the emergency order could reduce risk in the sector during successive waves of the pandemic. Doing so would require addressing chronic staffing shortages, by accelerating the training of LTC workers and by promoting retention in the field by ensuring all workers have fair and full-time pay with benefits and a career ladder to support their advancement. ${ }^{26}$

\section{$\underline{\text { Limitations }}$}

The mobility location data acquired from Veraset relies on GPS check-ins from several mobile phone applications. As such, individuals who do not use these applications or do not consent to sharing their data will not be captured. While this will underestimate absolute measures of mobility, the relative differences calculated between the periods are robust. Furthermore, a dearth in geospatial footprint data per facility limited the spatial accuracy in detectability of devices by a generalized 50 metre buffer although this sampling error was consistent across all facilities. Finally, we were not able to assess the temporal association between staff mobility and COVID-19 outbreaks in LTC homes as this would require longitudinal mobility data on a granular level.

\section{Conclusions and Implications}

The emergency order by the Ontario government limiting LTC staff to a single home sharply reduced mobility between LTC homes. The residual mobility between 79 (12.7\%) of Ontario's 623 LTC homes remains an potential vector for the importation of COVID-19 into LTC homes and should be the focus of efforts to reduce risk within the LTC sector during the COVID-19 pandemic. 
medRxiv preprint doi: https://doi.org/10.1101/2020.11.17.20231498; this version posted November 18, 2020. The copyright holder for this preprint (which was not certified by peer review) is the author/funder, who has granted medRxiv a license to display the preprint in perpetuity. It is made available under a CC-BY-NC-ND 4.0 International license .

Mobility changes between LTC homes in Ontario 8

\section{Conflicts of Interest}

NS is supported by the Department of Medicine's Eliot Phillipson Clinician-Scientist Training Program and the Clinician Investigator Program at the University of Toronto and the Vanier Canada Graduate Scholarship. AC holds the Schlegel Chair in Clinical Epidemiology and Aging at McMaster University. BlueDot is a social enterprise that develops digital technologies for public health. AW, SK, JF, and IIB received employment or consulting income from BlueDot during this research. 
medRxiv preprint doi: https://doi.org/10.1101/2020.11.17.20231498; this version posted November 18, 2020. The copyright holder for this preprint (which was not certified by peer review) is the author/funder, who has granted medRxiv a license to display the preprint in perpetuity.

It is made available under a CC-BY-NC-ND 4.0 International license .

Mobility changes between LTC homes in Ontario 9

Table 1: Mobility between Ontario long-term care homes before (March 1-April 21, 2020) and after (April 22-June 13, 2020) implementation of an emergency order limiting staff to working at one long-term care home or healthcare setting

\begin{tabular}{|c|c|c|c|c|c|c|c|c|c|}
\hline & & & mes wit & a Conne & & Averag & $\#$ of $\mathrm{Co}$ & nections & er home \\
\hline & $\mathrm{n}$ & Before & After & $\%$ diff & $p^{1}$ & Before & After & $\%$ diff & $p^{2}$ \\
\hline Overall & 623 & $42.7 \%$ & $12.7 \%$ & $-70.3 \%$ & $<0.001$ & 3.90 & 0.77 & $-80.3 \%$ & $<0.001$ \\
\hline Profit Status & & & & & & & & & \\
\hline For-profit & 360 & $43.1 \%$ & $14.7 \%$ & $-65.9 \%$ & $<0.001$ & 3.94 & 0.94 & $-76.1 \%$ & $<0.001$ \\
\hline Not-for-profit & 162 & $46.3 \%$ & $11.1 \%$ & $-76.0 \%$ & $<0.001$ & 4.02 & 0.50 & $-87.6 \%$ & $<0.001$ \\
\hline Municipal & 101 & $35.6 \%$ & $7.9 \%$ & $-77.8 \%$ & $<0.001$ & 3.47 & 0.60 & $-82.7 \%$ & $<0.001$ \\
\hline Chain Type & & & & & & & & & \\
\hline Large $(\geq 20)$ & 145 & $50.3 \%$ & $17.9 \%$ & $-64.4 \%$ & $<0.001$ & 5.16 & 1.50 & $-70.9 \%$ & $<0.001$ \\
\hline Small (2-19) & 210 & $44.3 \%$ & $13.3 \%$ & $-70.0 \%$ & $<0.001$ & 3.95 & 0.58 & $-85.3 \%$ & $<0.001$ \\
\hline Single home & 268 & $37.3 \%$ & $9.3 \%$ & $-75.1 \%$ & $<0.001$ & 3.15 & 0.53 & $-83.2 \%$ & $<0.001$ \\
\hline Home Size & & & & & & & & & \\
\hline$\geq 200$ beds & 76 & $67.1 \%$ & $30.2 \%$ & $-55.0 \%$ & $<0.001$ & 8.08 & 2.58 & $-68.1 \%$ & $<0.001$ \\
\hline $100-199$ beds & 201 & $52.0 \%$ & $15.3 \%$ & $-70.6 \%$ & $<0.001$ & 5.23 & 0.91 & $-82.6 \%$ & $<0.001$ \\
\hline $51-100$ beds & 281 & $27.8 \%$ & $6.0 \%$ & $-78.4 \%$ & $<0.001$ & 1.53 & 0.13 & $-91.5 \%$ & $<0.001$ \\
\hline$\leq 50$ beds & 65 & $20.0 \%$ & $1.5 \%$ & $-92.5 \%$ & $<0.001$ & 0.47 & 0.03 & $-93.6 \%$ & $<0.001$ \\
\hline $\begin{array}{l}\text { Community Size } \\
\text { (population) }\end{array}$ & & & & & & & & & \\
\hline$\geq 500,000$ & 255 & $65.9 \%$ & $21.6 \%$ & $-67.2 \%$ & $<0.001$ & 7.56 & 1.65 & $-78.2 \%$ & $<0.001$ \\
\hline $100,00-499,999$ & 225 & $32.4 \%$ & $8.0 \%$ & $-75.3 \%$ & $<0.001$ & 1.83 & 0.24 & $-86.9 \%$ & $<0.001$ \\
\hline$<10,000$ (rural) & 143 & $17.5 \%$ & $3.5 \%$ & $-80.0 \%$ & $<0.001$ & 0.53 & 0.06 & $-88.7 \%$ & $<0.001$ \\
\hline
\end{tabular}

1. McNemar's test

2. Wilcoxon rank-sum test 
medRxiv preprint doi: https://doi.org/10.1101/2020.11.17.20231498; this version posted November 18, 2020. The copyright holder for this preprint (which was not certified by peer review) is the author/funder, who has granted medRxiv a license to display the preprint in perpetuity.

It is made available under a CC-BY-NC-ND 4.0 International license .

Mobility changes between LTC homes in Ontario 10

Figure 1: Network connectivity diagrams before and after emergency order limiting staff to working at one long-term care home or healthcare setting

Before Restrictions (March 1 to April 21, 2020)

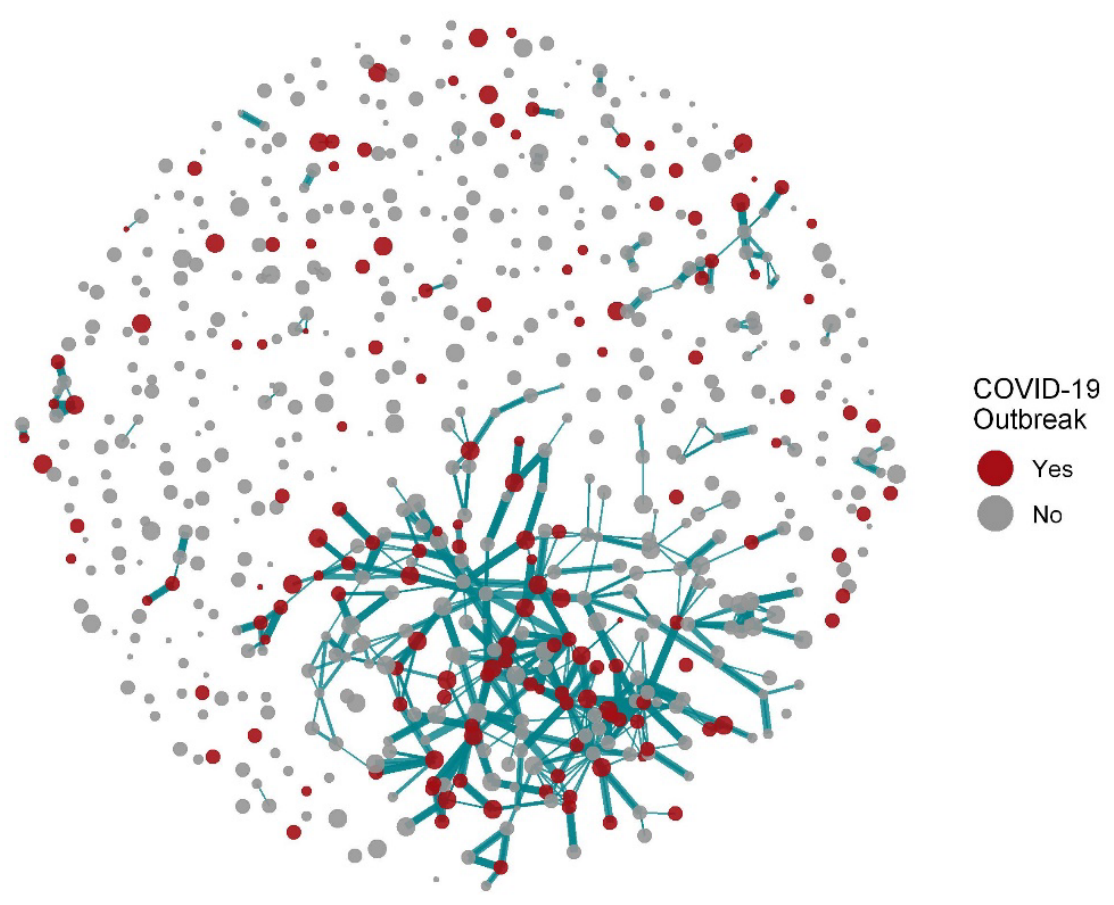

After Restrictions (April 22 to June 13, 2020)

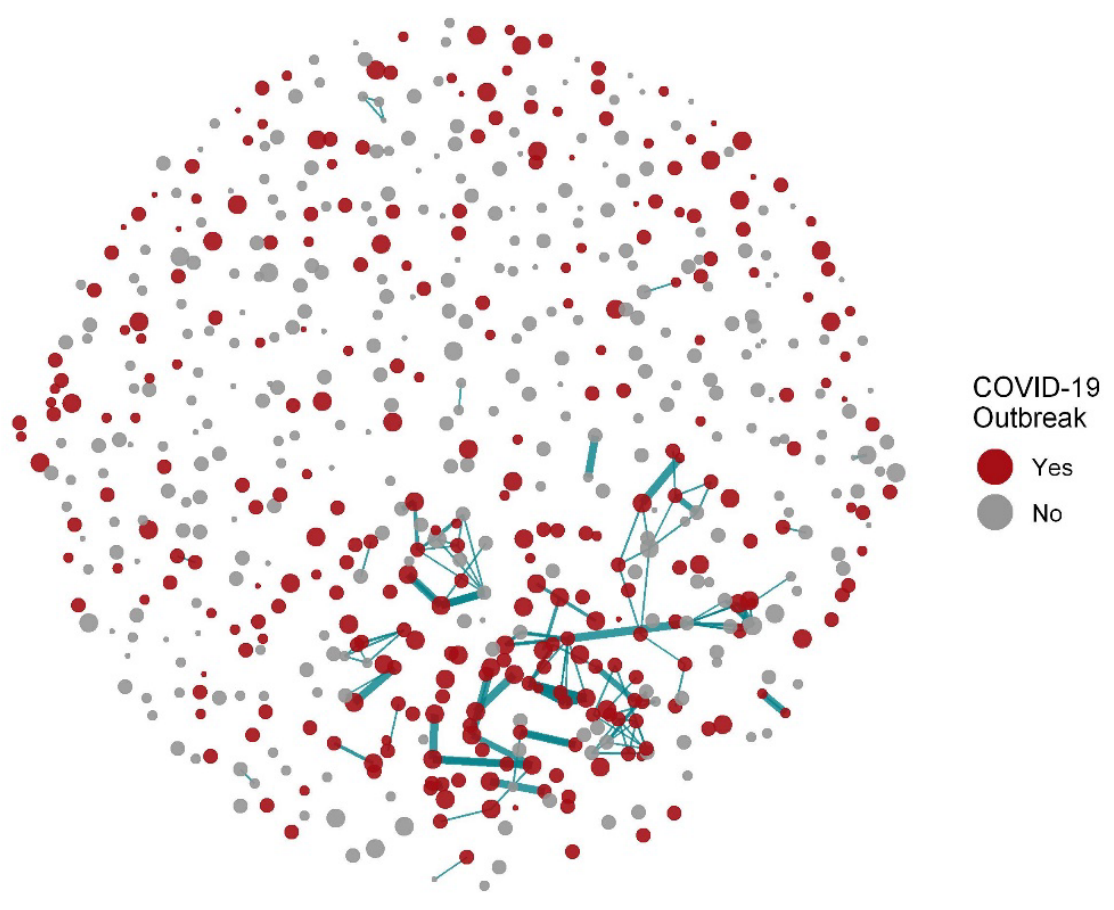


medRxiv preprint doi: https://doi.org/10.1101/2020.11.17.20231498; this version posted November 18, 2020. The copyright holder for this preprint (which was not certified by peer review) is the author/funder, who has granted medRxiv a license to display the preprint in perpetuity.

It is made available under a CC-BY-NC-ND 4.0 International license .

Mobility changes between LTC homes in Ontario 11

\section{References}

1. Ouslander JG, Grabowski DC. COVID-19 in Nursing Homes: Calming the Perfect Storm. J Am Geriatr Soc 2020;68:2153-2162.

2. Sepulveda ER, Stall NM, Sinha SK. A Comparison of COVID-19 Mortality Rates among Long-Term Care Residents in 12 OECD Countries. J Am Med Dir Assoc September 2020.

3. Yourish K, Lai KKR, Ivory D, et al. One-Third of All U.S. Coronavirus Deaths Are Nursing Home Residents or Workers. The New York Times.

https://www.nytimes.com/interactive/2020/05/09/us/coronavirus-cases-nursing-homes-us.html. Published May 9, 2020. Accessed November 13, 2020.

4. Applegate WB, Ouslander JG. COVID-19 Presents High Risk to Older Persons. J Am Geriatr Soc 2020;68:681-681.

5. McMichael TM, Currie DW, Clark S, et al. Epidemiology of Covid-19 in a Long-Term Care Facility in King County, Washington. N Engl J Med 2020;382:2005-2011.

6. Fisman DN, Bogoch I, Lapointe-Shaw L, et al. Risk Factors Associated With Mortality Among Residents With Coronavirus Disease 2019 (COVID-19) in Long-term Care Facilities in Ontario, Canada. JAMA Netw Open 2020;3:e2015957.

7. Chen MK, Chevalier J, Long E. Nursing Home Staff Networks and COVID-19. Cambridge, MA: National Bureau of Economic Research, 2020:w27608. http://www.nber.org/papers/w27608.pdf. Accessed October 22, 2020.

8. Liu M, Maxwell CJ, Armstrong P, et al. COVID-19 in long-term care homes in Ontario and British Columbia. CMAJ January 2020.

9. Houtven CHV, DePasquale N, Coe NB. Essential Long-Term Care Workers Commonly Hold Second Jobs and Double- or Triple-Duty Caregiving Roles. J Am Geriatr Soc 2020;68:1657-1660.

10. Office of the Provinical Health Officer of British Columbia. Facility Staff Assignment Order., 2020. https://www2.gov.bc.ca/assets/gov/health/about-bc-s-health-care-system/office-of-the-provincialhealth-officer/covid-19/covid-19-pho-order-long-term-care-facility-staff-assignment.pdf.

11. Ontario Ramping Up Protection for Long-Term Care Residents.

https://news.ontario.ca/en/release/56681/ontario-ramping-up-protection-for-long-term-care. Accessed October 22, 2020.

12. Center for Clinical Standards and Quality/Quality, Safety \& Oversight Group. Guidance for Infection Control and Prevention of Coronavirus Disease 2019 (COVID-19) in Nursing Homes (REVISED)., 2020. https://www.cms.gov/files/document/qso-20-14-nh-revised.pdf.

13. Long-term care staffing study | Ontario.ca. https://www.ontario.ca/page/long-term-care-staffingstudy. Accessed October 29, 2020.

14. Hsu AT, Berta W, Coyte PC, et al. Staffing in Ontario's Long-Term Care Homes: Differences by Profit Status and Chain Ownership. Can J Aging Rev Can Vieil 2016;35:175-189. 
medRxiv preprint doi: https://doi.org/10.1101/2020.11.17.20231498; this version posted November 18, 2020. The copyright holder for this preprint (which was not certified by peer review) is the author/funder, who has granted medRxiv a license to display the preprint in perpetuity.

It is made available under a CC-BY-NC-ND 4.0 International license .

Mobility changes between LTC homes in Ontario

15. Ontario long-term care plan raises concerns about loopholes, staff wages amid COVID-19 pandemic.https://www.theglobeandmail.com/canada/article-ontario-long-term-care-plan-raisesconcerns-about-loopholes-staff/. Accessed October 29, 2020.

16. Ontario Long-term care association. This Is Long-Term Care 2019., 2019. https://www.oltca.com/OLTCA/Documents/Reports/TILTC2019web.pdf.

17. Watts A, Au NH, Thomas-Bachli A, et al. Potential for inter-state spread of Covid-19 from Arizona, USA: analysis of mobile device location and commercial flight data. J Travel Med.

18. Ontario Regulation 146/20: LIMITING WORK TO A SINGLE LONG-TERM CARE HOME., 2020. https://www.ontario.ca/laws/regulation/200146.

19. Ministry of Health Service Provider Locations. https://geohub.lio.gov.on.ca/datasets/ministry-ofhealth-service-provider-locations. Accessed October 22, 2020.

20. Government of Canada SC. The Open Database of Buildings. https://www.statcan.gc.ca/eng/lode/databases/odb. Published June 13, 2018. Accessed October $22,2020$.

21. Schloerke B, Cook D, Larmarange J, et al. GGally: Extension to “Ggplot2.”, 2020. https://CRAN.Rproject.org/package=GGally. Accessed October 22, 2020.

22. R Core Team. R: A Language and Environment for Statistical Computing. Vienna, Austria, 2020.

23. Preparedness E. B.C. COVID-19 response update|BC Gov News. https://news.gov.bc.ca/releases/2020EMBC0014-000575. Published March 26, 2020. Accessed October 22, 2020.

24. Coronavirus: B.C. confirms 66 new cases, no new deaths. Global News. https://globalnews.ca/news/6737594/bc-coronavirus-update-thursday-march-26/. Accessed October 29, 2020.

25. Sehra ST, George M, Wiebe DJ, et al. Cell Phone Activity in Categories of Places and Associations With Growth in Cases of COVID-19 in the US. JAMA Intern Med August 2020.

26. Royal Society of Canada. Restoring Trust: COVID-19 and The Future of Long-Term Care | The Royal Society of Canada., 2020. https://rsc-src.ca/en/restoring-trust-covid-19-and-future-long-term-care. Accessed October 29, 2020. 
Before Restrictions (March 1 to April 21, 2020)

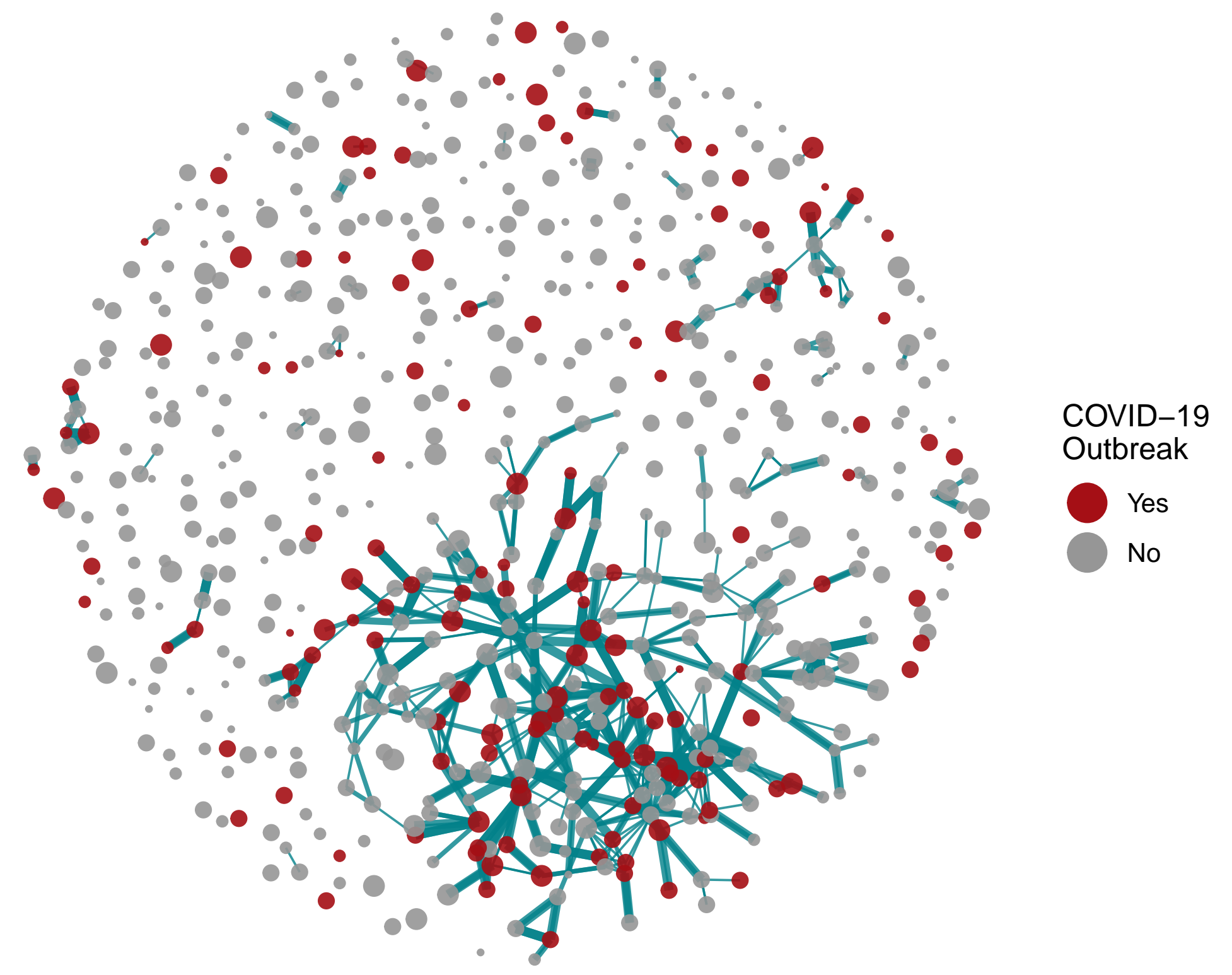


After Restrictions (April 22 to June 13, 2020)

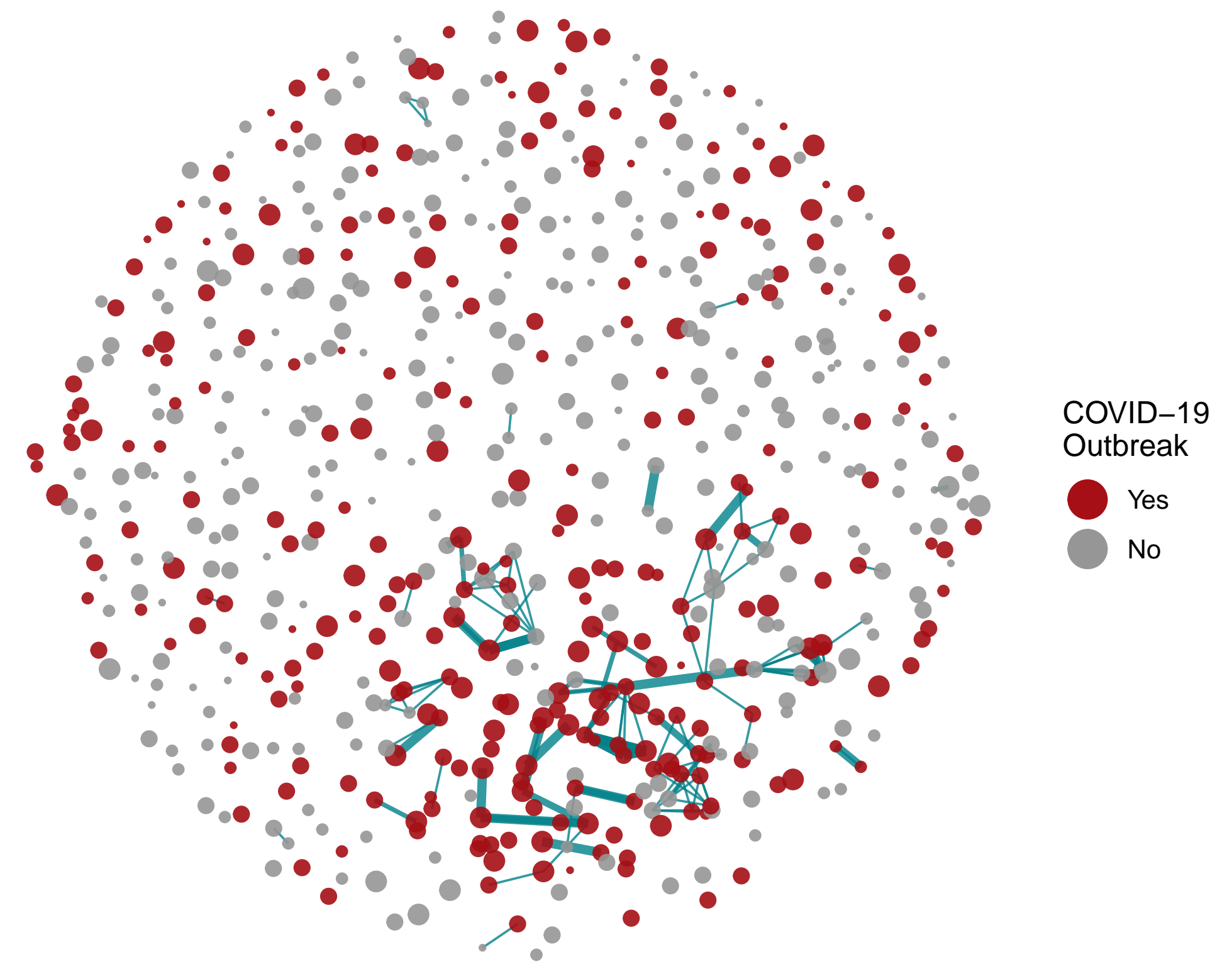

